\section{Cervical necrotizing fasciitis due to periapical infection of the mandibular canine tooth}

\section{Alt çene kanin dişinin periapikal enfeksiyonuna bağlı olarak gelişen servikal nekrotizan fasiit}

\section{R.A. Senem Yıldırımtürk}

Istanbul University, Faculty of Dentistry,

Department of Oral and Maxillofacial Surgery, Istanbul

\section{Dr. Eren Yilmaz}

Istanbul University, Faculty of Medicine, Department of Otorhinolaryngology, Head and Neck Surgery, Istanbul

\section{Dr. Beldan Polat}

Istanbul University, Faculty of Medicine, Department of Otorhinolaryngology, Head and Neck Surgery, Istanbul

\section{Assoc. Prof. Dr. Bora Basaran}

Istanbul University, Faculty of Medicine, Department of Otorhinolaryngology, Head and Neck Surgery, Istanbul

\section{Assoc. Prof. Dr. Yiğit Şirin}

Istanbul University, Faculty of Dentistry,

Department of Oral and Maxillofacial Surgery, Istanbul

Received: 5 June 2017

Accepted: 25 July 2017

doi: 10.5505/yeditepe.2017. 38258

\section{Corresponding author:}

R.A. Senem Yildirimturk

Istanbul University Faculty of Dentistry, Department of Oral and Maxillofacial Surgery 34093 Capa/Fatih/ İstanbul/TURKEY

Phone: +902124142020 / 30377

Fax: +902125312230

E-mail: senem.yildirimturk@istanbul.edu.tr

\section{SUMMARY}

The infection of the cervical region is called Cervical NF (CNF) which can spread rapidly along the fascial planes to other regions of the neck. It may lead to the thrombosis, destruction of the superficial nerves and skin necrosis. Odontogenic infections of mandibular molars are the most common causes for CNF. More than half of the patients with CNF have diabetes mellitus (DM) as an underlying systemic disease. Early diagnosis based on physical examination, laboratory tests and radiographic evaluation, as well as appropriate surgical management are critical in reducing morbidity and mortality. Initial treatment of CNF should include immediate hospitalization, hemodynamic and respiratory evaluation, effective high dose broad spectrum intravenous antibiotic therapy, surgical debridement of necrotic tissue and nutritional support. The aim of this report is to present a rare case of CNF originating from an infected mandibular canine in a patient with uncontrolled DM with special emphasis to the clinical characteristics of this lethal condition.

Keywords: Necrotizing fasciitis, odontogenic infection, soft tissue infection, diabetes mellitus

\section{ÖZET}

Nekrotizan fasiit (NF) nadir olarak görülen ve derin dermis tabakası, cilt altı dokular ve fasiyal planları tutan ciddi bir enfeksiyondur. NF ağırlıklı olarak ekstremitelerde, perineal bölgede ve karın duvarında oluşum gösterir. Boyun bölgesinde görülen ve çok hızlı bir şekilde yayılan enfeksiyona Servikal NF (SNF) adı verilir. SNF kılcal damarların trombozisine, yüzeyel sinirlerin tahribatına ve cilt nekrozuna neden olur. SNF nin en sık görülme nedeni alt büyük azı dişlerinin periapikal enfeksiyonudur. SNF görülen hastaların büyük bir çoğunluğunda altta yatan sistemik hastalık diabetes mellitustur (DM). Fizik muayene bulguları, laboratuar testleri, radyografik değerlendirmeye dayalı erken teşhis ve uygun cerrahi müdahale morbidite ve mortaliteyi azaltmada önem taşır. SNF nin başlangıç tedavisi acil hastane yatışı, hemodinamiğin ve solunumun değerlendirilmesi, yüksek doz geniş spektrumlu intravenöz antibiyotik tedavisi, nekrotik dokuların cerrahi debridmanı ve beslenme desteğini içermelidir. Bu olgu raporunda; kontrolsüz DM si olan hastada alt kanin dişin periapikal enfeksiyonundan kaynaklanan SNF olgusu bildirilmiş ve bu letal durumun klinik özelliklerine vurgu yapılmıştır.

Anahtar kelimeler: Nekrotizan Fasiit, odontojenik enfeksiyon, yumuşak doku enfeksiyonu, diabetes mellitus

\section{INTRODUCTION}

Necrotizing fasciitis (NF) is a rare, life-threatening soft tissue infection which affects the deep layers of dermis, superficial fascia and subcutaneous tissues. ${ }^{1}$ Diabetes mellitus (DM) immunodeficiency disorders, malnutrition, smoking, alcohol consumption and advanced age are predisposing factors for NF. ${ }^{2,3}$ Cervical NF (CNF), is a relatively uncommon but fatal 
condition (\%1 to $10 \%$ among all NF cases) which is mostly associated with DM..$^{1-4}$ Causative factors of CNF include mainly infections of odontogenic origin ${ }^{3,5}$ which is followed by those of salivary gland, ear, skin and tonsils. ${ }^{5}$ Mortality rates of CNF have been reported as $0 \%$ to $27.6 \% .2$ As the treatment delays, CNF may spread along the fascial planes leading to mediastinitis, airway obstruction, septic shock and death. ${ }^{2}$ The aim of this report is to present a rare case of CNF originating from an infected mandibular canine in a patient who has uncontrolled DM with special emphasis to the clinical characteristics of this condition.

\section{CASE REPORT}

In December 2015, a 57-year-old male patient was referred with complaints of dysphagia, severe pain and prominent swelling in his cervical region. Ten days prior to his admission, he had felt severe pain in the right mandible and had visited a private dental clinic. There, he had been initially prescribed ampicillin-sulbactam $375 \mathrm{mg}$ per oral (p.o.) twice daily for five days. Later, he had been given an unknown dose of ampicillin-sulbactam intravenous (i.v.) for five days but his overall condition had not improved. The medical history of the patient revealed uncontrolled diabetes, hypertension and ischemic heart disease. Extraoral examination revealed erythema, edema and purple-colored skin tissue in the cervical region (Figure 1).

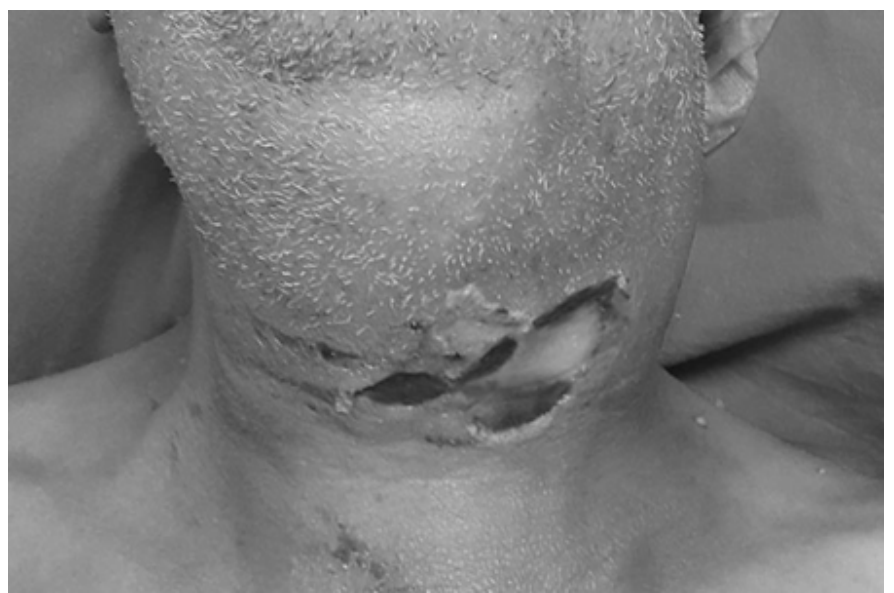

Figure 1. Clinical view of skin necrosis and erythema in neighboring tissue in cervical region.

Intraoral examination showed only two mandibular canine teeth. A large cavity was observed in the right canine which also demonstrated Class III clinical mobility and swelling in the apical region (Figure 2).

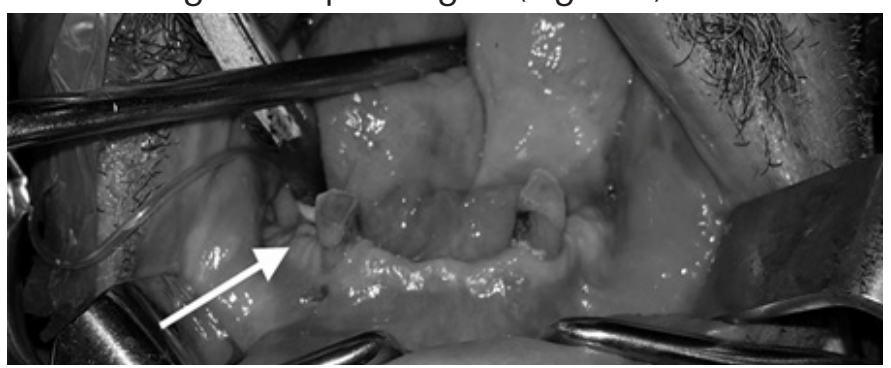

Figure 2. Intraoral view showing the mandibular right canine tooth which is the source of infection (white arrow).
The floor of the mouth was firm, edematous and tender to palpation. A necrotic area in the mucosa of the right vallecula and pus discharge were observed. Diffuse edema spreading from the floor of the mouth to the midline of the neck region was detected. Necrosis extending from skin to the superficial fascia and infrahyoid muscles were noted in physical examination.

The patient's body temperature was $37^{\circ} \mathrm{C}$ and white blood cell count (WBC) was 27x $103 \mathrm{~mm}^{3}$ while the level of C-reactive protein (CRP) and fasted blood glucose were $263 \mathrm{mg} / \mathrm{L}$ and $340 \mathrm{mg} / \mathrm{dL}$, respectively. Blood pressure was 140/80 mm Hg. Computed tomography (CT) with i.v. contrast revealed regions of hyperdensity and the presence of gas in the submandibular, submental and prelaryngeal areas as well as necrotic tissue in the right vallecular region involving the root of right mandibular canine (Figure 3).

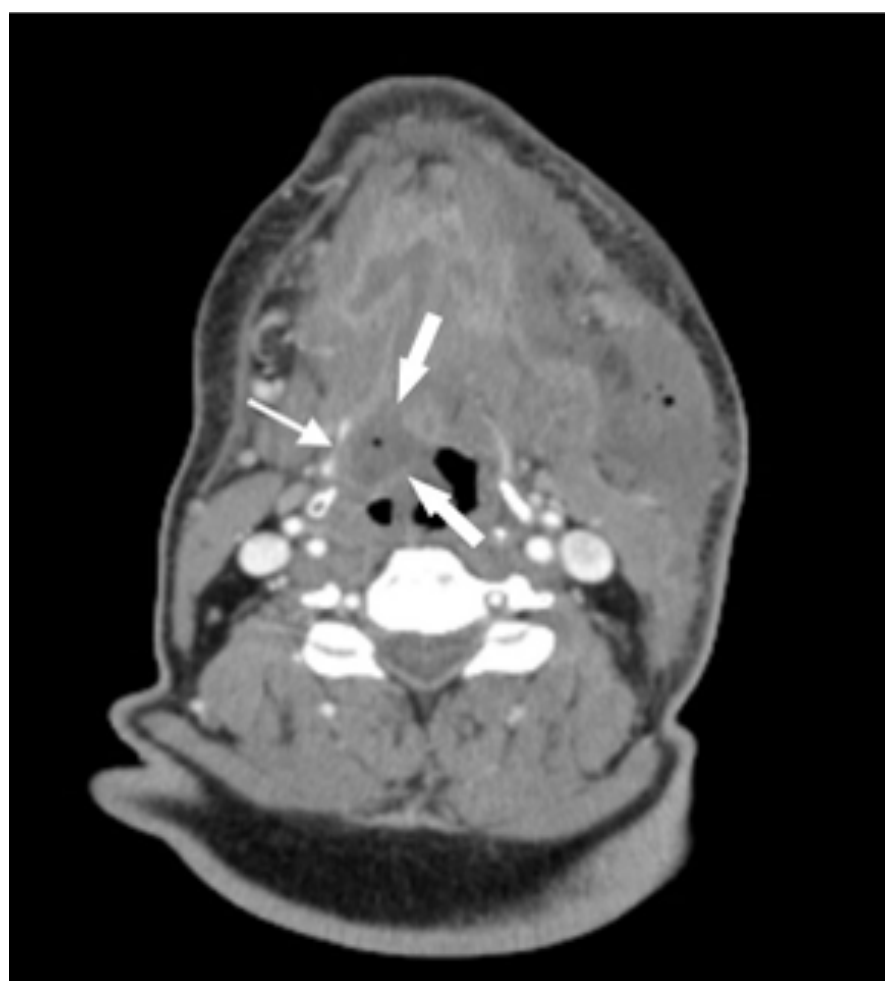

Figure 3. Axial computed tomography (CT) scan of the patient that shows diffuse, hyperdense fluid collection and necrotic tissue (white arrows).

Patient was immediately hospitalized and $4 \times 2 \mathrm{~g}$ daily i.v. ampicillin-sulbactam antibiotic treatment was started.

The patient was scheduled for urgent debridement of necrotic tissues under general anesthesia. Necrotic skin of approximately $5 \mathrm{~cm} \times 10 \mathrm{~cm}$ in size was excised and the debridement of the superficial and deep cervical fascial layers were performed (Figure 4A). Clear surgical margins were reached and the area was irrigated copiously with sterile saline and povidone-iodine solution (Figure 4B). The surgical defect area was left to heal by secondary intention. Both mandibular canines were extracted during the procedure. I.v. administration of clindamycin (3x 900 mg daily) was added to the pre-existing antibiotic therapy (ampicillin-sulbactam $4 \times 2 \mathrm{~g}$ daily, i.v.) postoperatively. As the emergency situation was under control, the patient 
was consulted with the Department of Endocrinology in order to effectively manage his blood glucose levels.

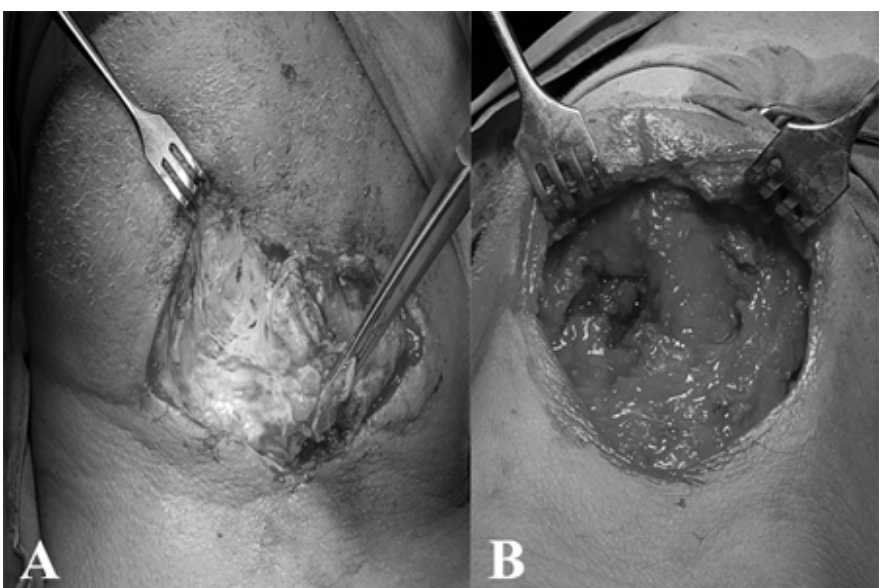

Figure 4.A Diffuse necrotic areas revealed after excision of skin tissue. (B) Intraop erative view of the surgical site following debridement of necrotic tissues.

A prominent decrease in the levels of CRP $(13 \mathrm{mg} / \mathrm{dl})$ and blood glucose $(140 \mathrm{mg} / \mathrm{dl})$ were detected on the postoperative $12^{\text {th }}$ day. The patient was discharged from hospital two weeks after surgery. The patient was followed up monthly for the first 6 months and every other three months for the duration of 12 months. At one year follow-up visit, healing was found to be uneventful (Figure 5).

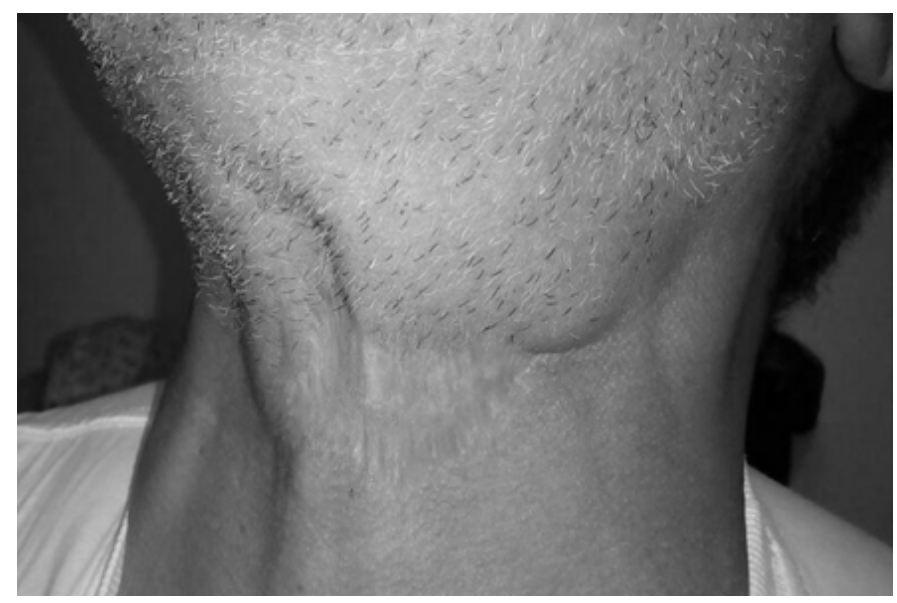

Figure 5. Clinical view of the cervical region at one year follow-up.

\section{DISCUSSION}

$\mathrm{NF}$ is characterized by the fast and progressive liquefaction of the fascia and fat tissue, generally due to an infection of polymicrobial origin. Patients, particularly the elders, who have an underlying disease were reported to be more prone to CNF than the people who do not have an immunodeficiency. ${ }^{1,2}$ Wong $^{6}$ investigated the determinants of mortality in patients with NF and stated that DM alone was found to be the only cause of NF progression in $46 \%-72 \%$ of the cases.

CNF mainly originates from odontogenic infections of molar teeth.7. 8 Tung-Yiu ${ }^{9}$ reported that, of all the odontogenic infections admitted to their clinic in a period of 10.5 years, the incidence of CNF was $2.6 \%$ and mandibular molars were the most common source, probably because the roots of first and second molar teeth are in close relationship with submandibular and submassateric spaces. ${ }^{3}$ However, in the present case, the source of the odontogenic infection was the right mandibular canine tooth.

In the early stages of CNF, it could not be distinguished from dental abscess formation. Panoramic radiographs, CT scans and/or Magnetic Resonance Imaging (MRI) should be obtained for accurate diagnosis. The findings of CT scans of the present case fulfilled the diagnostic criteria for NF. Early surgical intervention is the key to increase survival rates. McHenry ${ }^{10}$ have found a significant difference among the average time intervals from hospitalization to the surgery between non-surviving and surviving patients, which were reported as 90 and 25 hours, respectively. Accordingly, the present case was operated within the first 24 hours and routine re-examinations were performed for two weeks, twice daily.

\section{CONCLUSION}

CNF mostly originates from the mandibular molar teeth but canines should not be disregarded as possible sources of infection. Immediate surgical intervention is critical in reducing morbidity and mortality; therefore, time span between the diagnosis and the initiation of treatment is of utmost importance.

\section{REFERENCES}

1. Lin $C_{\text {, }}$. Necrotizing fasciitis of the head and neck: an analysis of 47 cases. Plast Reconstr Surg 2001; 107: 1684-1693.

2. Weiss A, Nelson P, Movahed R, Clarkson EDym H. Necrotizing fasciitis: review of the literature and case report. $J$ Oral Maxillofac Surg 2011; 69: 2786-2794.

3. Juncar M, Bran S, Juncar RI, Baciut MF, Baciut GOnisor-Gligor F. Odontogenic cervical necrotizing fasciitis, etiological aspects. Niger J Clin Pract 2016; 19: 391-396. 4. Lanisnik B, Cizmarevic B. Necrotizing fasciitis of the head and neck: 34 cases of a single institution experience. Eur Arch Otorhinolaryngol 2010; 267: 415-421.

5. Ugboko VI, Assam E, Oginni FO, Amole AO. Necrotising fasciitis of the head and neck: a review of the literature. Niger J Med 2001; 10: 6-10.

6. Wong $\mathrm{CH}$, . Necrotizing fasciitis: clinical presentation, microbiology, and determinants of mortality. J Bone Joint Surg Am 2003; 85-A: 1454-1460.

7. Song $\mathrm{CW}$, Yoon $\mathrm{HJ}$, Jung DW, Lee $\mathrm{SH}$. Cervical Necrotizing Fasciitis Caused by Dental Infection. Maxillofac Plast Reconstr Surg 2014; 36: 67-72.

8. Umeda M, Minamikawa T, Komatsubara H, Shibuya $Y$, Yokoo SKomori T. Necrotizing fasciitis caused by dental infection: a retrospective analysis of 9 cases and a review of the literature. Oral Surg Oral Med Oral Pathol Oral Radiol Endod 2003; 95: 283-290.

9. Tung-Yiu W, Jehn-Shyun $H$, Ching-Hung CHung-An C. Cervical necrotizing fasciitis of odontogenic origin: a report of 11 cases. J Oral Maxillofac Surg 2000; 58: 13471352.

10. McHenry CR, Piotrowski JJ, Petrinic D, Malangoni MA. Determinants of mortality for necrotizing soft-tissue infections. Ann Surg 1995; 221: 558-563. 
